\title{
BMJ Global Health Power analysis in health policy and systems research: a guide to research conceptualisation
}

\author{
Stephanie M Topp (D) , , 1,2 Marta Schaaf (D),${ }^{3}$ Veena Sriram, ${ }^{4}$ Kerry Scott (D) , 5,6 \\ Sarah L Dalglish (1) , ${ }^{5,7}$ Erica Marie Nelson (D) , ${ }^{8}$ Rajasulochana SR (1) , \\ Arima Mishra (D) , ${ }^{10}$ Sumegha Asthana (D) , ${ }^{11}$ Rakesh Parashar, ${ }^{12}$ \\ Robert Marten (D) , ${ }^{13}$ João Gutemberg Quintas Costa, ${ }^{14}$ Emma Sacks (D) , \\ Rajeev BR, ${ }^{15}$ Katherine Ann V Reyes (D) ${ }^{16}$ Shweta Singh ${ }^{17}$
}

To cite: Topp SM, Schaaf M, Sriram V, et al. Power analysis in health policy and systems research: a guide to research conceptualisation. BMJ Global Health

2021;6:e007268. doi:10.1136/ bmjgh-2021-007268

Handling editor Seye Abimbola

SMT, MS and VS are joint first authors.

Received 24 August 2021 Accepted 12 0ctober 2021

\section{Check for updates}

\section{Author(s) (or their} employer(s)) 2021. Re-use permitted under CC BY-NC. No commercial re-use. See rights and permissions. Published by BMJ.

For numbered affiliations see end of article.

Correspondence to Dr Stephanie M Topp; globalstopp@gmail.com

\section{ABSTRACT}

Power is a growing area of study for researchers and practitioners working in the field of health policy and systems research (HPSR). Theoretical development and empirical research on power are crucial for providing deeper, more nuanced understandings of the mechanisms and structures leading to social inequities and health disparities; placing contemporary policy concerns in a wider historical, political and social context; and for contributing to the (re)design or reform of health systems to drive progress towards improved health outcomes. Nonetheless, explicit analyses of power in HPSR remain relatively infrequent, and there are no comprehensive resources that serve as theoretical and methodological starting points. This paper aims to fill this gap by providing a consolidated guide to researchers wishing to consider, design and conduct power analyses of health policies or systems. This practice article presents a synthesis of theoretical and conceptual understandings of power; describes methodologies and approaches for conducting power analyses; discusses how they might be appropriately combined; and throughout reflects on the importance of engaging with positionality through reflexive praxis. Expanding research on power in health policy and systems will generate key insights needed to address underlying drivers of health disparities and strengthen health systems for all.

\section{INTRODUCTION}

Power is defined as the ability or capacity to 'do something or act in a particular way' and to 'direct or influence the behaviour of others or the course of events'. ${ }^{1}$ Relationships of power shape societies, and in turn, health policies, services and outcomes. ${ }^{2}$ Power dynamics-or the relational power that manifests in the interaction among individuals and organisations-also influence health systems, or 'the organizations, people and actions whose primary intent is to promote, restore or maintain health'. ${ }^{3}$ The universe of power

\section{Summary box}

Analysing how power shapes health policy and systems is critical to identifying underlying factors driving health disparities, health systems challenges and societal inequities.

- Power is complex to explore conceptually, theoretically and methodologically, and explicit analyses of power in health policy and systems remain relatively infrequent.

- There is no consolidated resource that provides health policy and systems researchers with an empirical, theoretical and methodological starting point on power.

- We introduce a new framework for identifying and refining discrete areas of inquiry for power-focused health policy and systems research.

- Theoretical and conceptual understandings of power are summarised and linked to a selection of methodologies and methods for conducting analyses.

- Illustrative examples of combining theory and methodology to analyse different levels of power in health policy and systems research are provided.

- Expanding research on power in health policy and systems in all contexts will generate insights needed to address underlying drivers of health disparities and strengthen health systems for all.

dynamics that are pertinent to the study of health policies and systems includes diverse types and locations of policy, social, implementation and political processes. Power dynamics have also influenced health systems planning and research, by defining what is seen as a health system, and the translation or adaptation of health systems models across distinct geographic contexts over time. ${ }^{45}$

Studying power is thus a core concern of researchers and practitioners working in the field of health policy and systems research (HPSR), an interdisciplinary, problemdriven field focused on understanding and 
strengthening of multilevel systems and policies. ${ }^{6}$ Accelerating theoretical development and empirical research on power in this domain is crucial for several reasons. First, it provides a deeper, more nuanced understanding of the mechanisms and structures that lead to social inequities and health disparities. ${ }^{7}$ Second, it reveals historical patterns entrenched in health and social systems, allowing contemporary policy concerns to be seen in a wider context and lessons to be drawn from these trends. ${ }^{8}$ Third, analysing power can contribute to the (re)design or reform of health systems to redress imbalances and progress towards improved health outcomes. ${ }^{9}$

Studies incorporating examinations of power in public health and HPSR have gradually increased in number, including, for example, analyses of accountability, political prioritisation, commercial determinants of health, determinants of universal health coverage and state sovereignty in health agenda setting. ${ }^{10-15}$ Nonetheless, explicit analyses of power in HPSR remain relatively infrequent. ${ }^{716}$ Lack of a power-specific lens may reflect the continued dominance of biomedical and behaviouralist approaches in health research and funding, limitations stemming from the political economy of research funding and agendas, and reluctance among institutions and individuals to examine their own role in perpetuating existing power dynamics. ${ }^{17} 18$ Power is also complex to examine conceptually, theoretically and methodologically. Seminal publications providing guidance on different aspects of power research include Erasmus and Gilson's ${ }^{19}$ paper on investigating organisational power; the health policy analysis reader edited by Gilson et $a l,{ }^{20}$ and Loewenson et al $\mathrm{s}^{21}$ methods reader on participatory action research (PAR). Recent resources also provide conceptual overviews of power. ${ }^{7922}$ However, there remains no comprehensive resource that can serve as a theoretical and methodological starting point for aspiring power researchers, irrespective of disciplinary orientation or area of HPSR interest. ${ }^{16}$

This paper aims to fill this gap, building on the abovementioned resources but providing a more consolidated guide to researchers wishing to consider, design and conduct power analyses of health policies or systems. Recognising the expansive and interlinked nature of power relations, we focus this article on the different ways to research power as it manifests in health policies and systems. We also engage with literature on the social determinants of health insofar as these determinants impact health policies and systems.

This project emerged from the Social Science Approaches for Research and Engagement in Health Policy and Systems (SHAPES) thematic working group of Health Systems Global. SHAPES members (SMT, VS, MS and KS) with interest and expertise in power analyses reached out to the wider network and requested other interested researchers and practitioners to join the project. Recognising that expertise can take many forms, no criteria were placed on participation other than an interest in the topic and willingness to contribute to the paper's development. The group was ultimately comprised of researchers from academic institutions, research organisations and multilateral agencies, in both the Global North (eight) and Global South (six) all of whom have experiential knowledge of assessing and negotiating power in health systems at various levels, and a number of whom have published in this area.

The process to develop this resource began in 2019. Members of the original group (SMT, VS, MS and KS) first prepared an outline of the paper via virtual and email discussions among group members. That outline was then divided into sections on theory, methodology and reflexivity, and section leads were appointed by a process of consensus. Group members volunteered to work on a section or sections based on experience and ability to input. Literature was sourced from database searches combined with expert guidance from group members. Working group leads organised the work of these sections and led drafting. Section drafts were reviewed by each group and then the full group, and two external researchers were invited to provide feedback on specific aspects of the paper. Online supplemental appendix 1 illustrates the iterative process by which the ideas were conceptualised, synthesised and agreed on at different stages of the paper drafting. All authors also read and commented on at least one version of the final paper. As a whole, the project was collaborative and worked from the logic of crowd-sourcing among a diverse set of authors engaged in HPSR.

\section{DOING POWER ANALYSES IN HEALTH POLICIES AND SYSTEMS RESEARCH}

This paper outlines key considerations and principles for power analyses in health policies and systems research throughout the research cycle. The paper is divided into three sections. The first section starts by discussing the identification of a research topic and presents three overarching empirical 'sites'-or discrete areas of inquiry-for power-focused HPSR. The empirical sites offer a starting point for study design by providing researchers with ways to reflect on and refine their research question. This section also highlights researchers' positionality and its influence on the whole research process. The second section provides an introduction to (and tabular summary of) theories useful for analysing power, demonstrating each theory's relationship to one or more of the empirical sites. Finally, the third section of the paper introduces a selection of methodologies, considers their usefulness in the context of different types of power analyses and discusses how they, too, must be selected with consideration for the research question, the researcher's positionality and alignment with theory. The ideas presented in this paper apply to all geographic contexts; however, we draw largely on HPSR literature from lowincome and middle-income countries. This paper does not engage extensively with the use of specific data collection tools or methods (eg, interviews, observations and 


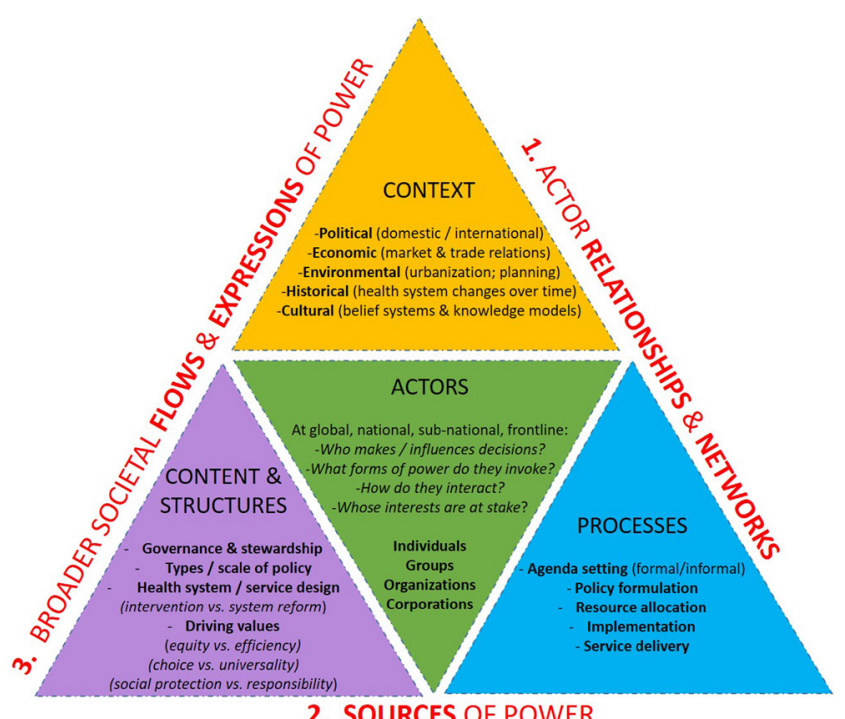

2. SOURCES OF POWER

Figure 1 Three empirical sites of power research in health policy and systems.

document review) associated with a given methodology, as other resources address these topics in detail. ${ }^{19} 212324$

\section{Identifying a topic}

Power is imposed, negotiated and contested in diverse ways in the context of health policy formulation and implementation and health systems functioning. Research into power in the field of HPSR generally focuses on how the 'expression' of power enables or blocks health system change or policy implementation and what types of power are implicated in the process. ${ }^{1620}$ From these two broad areas of focus, we discern three main sites of empirical work on power in the health policy and systems field, recognising that these three sites overlap significantly. These are: (1) actor relationships and networks; (2) sources of power and (3) societal flows and expressions of power.

In figure 1, we locate each of these empirical sites of power research around an adapted version of Walt and Gilson's ${ }^{25}$ seminal Policy Triangle. This figure highlights that applied research on power cannot be conducted in isolation from the actors, context, content, structures and processes of the policy or system in focus. By demonstrating the link between actors, context, and structures and broad areas of power research, the three empirical sites are intended to provide a point of departure for the researcher to consider what is the issue or topic of interest. We expand on each of these empirical sites further below.

\section{Empirical site 1: actor relationships and networks}

The role and manifestations of power in actor relationships and networks comprise an important site of empirical research on power in HPSR. We list this site first because we understand health systems as social systems, ${ }^{6}$ fundamentally shaped by the values, intentions and relationships of the human and organisational actors within them. As illustrated in the central green triangle in figure 1, questions about power relating to actor relationships and networks include foundational enquiries about which individuals and organisations make and influence (health) policy and system decisions, how they relate to one another and why.

\section{Empirical site 2: sources of power}

As outlined in Sriram et $a l^{16}$ and Moon ${ }^{22}$, a substantial body of theory is directed towards understanding how actors draw on power from particular sources. ${ }^{1622}$ Sources of power thus represent a second important grouping of research on power in HPSR. Some methodologies, particularly those based in political science and economic theory, can describe and problematise key sources of power, such as material capital; technical expertise; political and bureaucratic position and influence; and forms of cultural capital and power gained from title, education and knowledge. Resultant research can provide analyses regarding which actors are impacting processes, from where they derive their power and how their actions impact policy and systems. This empirical site focuses our attention on 'drivers of the drivers', surfacing the institutions, organisations and attributes that provide a fountainhead of power in HPSR.

\section{Empirical site 3: societal flows and expressions of power}

A third empirical site of power research in health policy and systems relates to the societal flows and expressions of power. Research on the exercise of power shows how power is expressed, leveraged and experienced to impact health policy and systems, and ultimately, health inequities. Reflecting the intersection among context, actors and structures, research related to flows and expressions of power can generate insights regarding how formal or informal institutions shape health policy-making and service delivery, or on the impact of prevailing ideologies regarding health policy on service delivery. ${ }^{26} 27$ Researchers may focus on the ways that health policies and systems shape inequities ${ }^{28}$ or the ways that different groups have accepted, adapted and subverted health systems, such as the dictates of colonial medicine ${ }^{29} 30$ or neocolonial or internalised colonial forms of public health practice. ${ }^{31} 32$

\section{ADDRESSING POWER WITHIN THE RESEARCH PROCESS: POSITIONALITY AND REFLEXIVITY}

In the process of issue identification and throughout the research process, it is critical to recognise the contested relationships of power that shape research itself. The nature of evidence in the fields of global health and health policy and systems research is contested, ${ }^{33-35}$ and the funding of evidence generation is politicised. ${ }^{18}{ }^{36}$ Researchers-whether investigating power or other aspects of health and society-must be willing to consider their own role as actors in a contested process. Health research broadly tends to reward-in professional status, resourcing and publishing-positivist and utilitarian 


\begin{tabular}{|c|c|}
\hline $\begin{array}{l}\text { Preliminary } \\
\text { steps }\end{array}$ & $\begin{array}{l}\text { Why are you (or the group you are part of) interested in asking these research questions? } \\
\text { Who do you expect will benefit from the outcomes of the research? } \\
\text { Who is part of the research team and how have you engaged with issues of positionality, personal status, } \\
\text { and diverse disciplinary backgrounds? } \\
\text { Who are you intending to work with, and what individual, group, institutional or social dimensions of power } \\
\text { may impact these partnership? } \\
\text { What voices or perspectives, particularly those of individuals or communities with direct experience of } \\
\text { your research topic, might you be missing? } \\
\text { How will you address issues of representation in your work, whether in terms of study design or in terms } \\
\text { of team composition? }\end{array}$ \\
\hline $\begin{array}{l}\text { Concurrent } \\
\text { steps }\end{array}$ & $\begin{array}{l}\text { What are the mechanisms for capturing dissent or alternative views in the research process, both within } \\
\text { the research team and with research participants and collaborators? } \\
\text { When analysing data, how do you account for differences in power among and between research } \\
\text { What types of dialogue and consultations can you offer within the research team and/or partners and how } \\
\text { frequently? } \\
\text { Whose voices are loudest within the process and can you do anything to shift that dynamic? } \\
\text { How are you building adaptive learning processes into the research to take into account diverse } \\
\text { perspectives and modify your approach accordingly? }\end{array}$ \\
\hline $\begin{array}{l}\text { Concluding } \\
\text { steps }\end{array}$ & $\begin{array}{l}\text { Who is included in the analytical process and are there opportunities to expand participation in 'meaning- } \\
\text { making' work? } \\
\text { How will you communicate and share the outcomes of your research, particularly with participants/ } \\
\text { respondents involved in the research? } \\
\text { Are there mechanisms in place to broaden your reach beyond 'usual suspects' (ie, academic circles)? } \\
\text { Have you put into place any process whereby data can be stored/archived in the places where it was } \\
\text { gathered? } \\
\text { Are equal opportunities given for authorship among the research team and/or with local collaborating } \\
\text { institutions or individuals? } \\
\text { What format will the publication(s) take and is there scope for writing in languages other than English and/ } \\
\text { or translation of results into other languages? } \\
\text { What other formats may results be presented in other than peer-reviewed journal articles? } \\
\text { If the work is going to be published in a peer-reviewed journal, will the resultant article(s) be open access? }\end{array}$ \\
\hline
\end{tabular}

approaches over humanistic and relativistic and/or interpretive ones, ${ }^{36}$ Northern voices over Southern ones ${ }^{37}$ and biomedical knowledge over other forms of knowledge. ${ }^{38}$ Indeed the positionality of researchers is present in the many forms of power and privilege that can distance them from the issues they are analysing. Researchers' professional positionality in the political economy of global health, as well as their individual lived experiences and attributes relating to race, caste, gender, class, ability and more, can significantly influence the choice of questions and (as discussed further) theories and methodologies used to enact analysis of those issues.

How should researchers engage with these challenges? There is no straightforward mechanism by which to operationalise critical reflexivity. Instead, building on the work of Sultana, ${ }^{39}$ Citrin, ${ }^{40}$ Mafuta et $a l,{ }^{41}$ Abimbola $^{37}$ Keikelame and Swartz ${ }^{42}$ and Pratt, ${ }^{43}$ we offer a set of questions in table 1 to guide reflection on power as it impacts a given research project. Researchers should consider: for whom they are designing and conducting data collection and analysis and writing up findings? And, how does this influence 'bad habits' that pervade global health research? ${ }^{44}$ However, discussions of power dynamics as they manifest in politics, social norms and otherwise is not a straightforward endeavour. Those who are brought in to collaborate in research processes, whether they be community members, health services representatives or funders, might be uncomfortable with an explicit focus on power relations. Shining a light on power asymmetries could create risks for collaborators or participants.

A conscious nurturing of critical reflexivity within all stages of a research process is a necessary component of ethical and rigorous praxis. However, analysing power while simultaneously maintaining awareness of the power relationships that structure the research endeavour itself is no easy feat. These questions and processes demand a more deliberative, bottom-up, time consuming approach to defining and answering research questions than is often enacted in HPSR. Prospective researchers of power should factor this time into their work. Since the political economy of global health and health policy and systems research can create incentives that undermine reflective, inclusive and transparent approaches to defining and answering research questions, ${ }^{18}$ these considerations should be taken into account from this initial step through the dissemination of findings and beyond. 


\section{REFINING THE RESEARCH QUESTION WITH THEORY AND METHODOLOGY}

The three empirical sites provide a launching pad for considering avenues for power inquiry for health policy and systems. In moving from a topic of interest to a more specific research question on power, and in conjunction with considerations of their own position and power, the researcher must consider their epistemological foundation (ie, what do we consider knowledge and how do we know it), the theories that provide a relevant analytical scaffolding, and concurrently, the methodologies that will enable appropriate collection, collation and analysis of data to that end. ${ }^{45}$

\section{Thinking about theory}

Theory helps to shape what we ask about power in HPSR. As a field, HPSR aims to generate research to inform policy and action ${ }^{24}$; this has implications for theory application, with the end goals of equity and justice often informing epistemological and theoretical positions. ${ }^{16}$

Some theories are foundational and address the nature of the state, society and human interaction; others are more operational in that they focus on discrete elements of the state, society and human interaction. As part of a process of reflexive research praxis, the entire research team should consider the guiding principles they wish to follow in their research and the implications that these choices have for theory choice and application. For example, researchers with applied interests may consider frameworks designed for this purpose, such as the PowerCube $^{46}$; conversely, researchers seeking a deeper theoretical understanding of mechanisms driving power imbalances may consider foundational theories, such as Max Weber's sources of authority, ${ }^{47}$

HPSR as a field has developed in dialogue with theories of power from diverse disciplines from the social sciences and humanities, including philosophy, sociology, political science, anthropology, feminist theory, postcolonial and gender studies, history, and international relations, among others. Most of the foundational theories cited in peer-reviewed social science literature (eg, Marx, Gramsci, Bourdieu, Foucault and Haugaard; see ref 9) originated in high-income countries, reflecting and perpetuating the discursive and material power held by scholars and academic institutions in these contexts. Many of these theories were developed in the 19th and 20th centuries, and while they describe macro-level processes that are still salient, they were not developed with contemporary phenomena-such as the proliferation of mobile technology and social media-in mind. Some scholars developed critical theories to analyse and critique power structures from the point of view of the oppressed. Theories of domination originating from feminist, postcolonial, Marxist, queer or critical race theory, among others, have been used to describe structural determinants of health, health policy and healthcare, and healthcare-seeking behaviours. ${ }^{4-50}$
Many contemporary critical theories focus on the intersectionality of systems of subordination ${ }^{51-53}$; researchers have begun to suggest ways of applying these theories in health policy analyses. ${ }^{545}$ Postcolonial literature and subaltern studies have not (yet) been applied extensively in HPSR $^{29}$ but have increasingly been cited in discussions about how to decolonise global health ${ }^{374256}$ and in recent scholarship on social inequities during the COVID-19 pandemic. $^{57}$

Other frameworks used in HPSR, particularly those from public policy studies, draw insights from social science theories to explore power without necessarily invoking power explicitly, such as street-level bureaucracy theory ${ }^{58}$ and diffusion theory. ${ }^{22}$ In table 2, we provide an illustrative list and brief explanation of influential theories of power that have informed or been applied to studies assessing health determinants, health policy and health systems. We recognise that the approaches described in this paper do not capture the full breadth and complexity of this topic, and a more detailed version of this table can be found in online supplemental appendix 2 .

\section{Pairing theory with methodology}

Different theories are better suited to analysing power asymmetries characterising each of the three empirical sites. With regards to empirical site 1, theories with potential for exploring actor relationships and networks may include Weber's three sources of authority ${ }^{47}$ : streetlevel bureaucracy ${ }^{58}$; feminist standpoint theory, ${ }^{50}$ critical race theory ${ }^{48}$ and Bourdieu's fields. ${ }^{59}$ Theories particularly relevant to examining the sources of power (empirical site 2) include Barnett and Duvall's taxonomy of power, ${ }^{60}$ Bourdieu's 'fields', ${ }^{59}$ Gramsci's concept of cultural hegemony ${ }^{61}$ and feminist approaches. ${ }^{5062}$ Theories relevant to expansive questions regarding how power is expressed and manifest in society at large (empirical site 3) may include Foucault's concept of knowledge/ power, ${ }^{63}$ Veneklasen and Miller's 'expressions of power' ${ }^{64}$ and Lukes' three faces of power. ${ }^{65}$

While theory helps to shape what we ask about power in HPSR, methodology shapes how we ask it and how we interpret the findings (figure 2). Below we provide an overview of 10 methodologies (broadly defined) that are of use in the context of the three empirical sites. The organisation of the methodologies under the empirical sites is merely illustrative. While some methodologies may be closely associated with a given empirical site (eg, social network analysis is associated with actor relationships and networks), many others are not. In conjunction with ongoing reflexive considerations of positionality, researchers choosing a methodology should consider their theoretical and epistemological position and the context of the research question, since the assumptions underlying the application of methodologies can be different (eg, the difference between an objectivist case study and an ethnography). Selection of methodologies should also consider for whom the research is being conducted, and whether the aim is to generate or further 
Table 2 Select theorists and theories useful for research on power in health policy and systems

\section{Theories useful for power} analysis Key constructs/brief description

Core texts and examples of application

\section{KEY THEORISTS and THEORIES}

Three faces and dimensions of Influenced by Marx and Durkheim, Lukes claims power is exercised in three ways: power, Stephen Lukes (1) the power to decide, (2) the power not to decide (ie, to set the agenda and circumscribe the limits of debate), (3) the power to influence people's wishes and

Lukes $2004^{65}$

Buse and Hawkes $2014^{120}$ Reynolds 2019 ${ }^{121}$ thoughts.

Three sources of authority, Max Weber described political authority as legitimate domination, distinct from concepts of Weber $1948^{47}$ Weber coercion and force. He defined three sources of political authority: traditional (derived Sriram et al $2018^{122}$ from established customs and social structures), charismatic (derived from the individual leader's characteristics) and rational-legal authority (derived from the formal rules and laws of the state).

'Fields,' Pierre Bourdieu Bourdieu proposed the concepts of fields - social domains characterised by specific logics and norms, and peopled by actors with varying levels of power. Actors in fields use forms of capital (economic, cultural, social or symbolic) to advance their selfinterest and preferences.

Biopower, Michel Foucault

Foucault's influential concept of 'power/knowledge' holds that rather than being an instrument of power, knowledge is constitutive and inseparable from it. In 'Discipline and Punish', Foucault discusses how modern institutions and techniques of control created systems of disciplinary power. He also contrasted older forms of 'sovereign' power, founded on violence, with modern 'biopower', which influences life by administration, optimisation and regulation.

Taxonomy of power, Michael Barnett and Raymond Duvall

Barnett and Duvall's framework seeks to understand how states negotiate policy processes in the international sphere. They differentiate between direct forms of power (compulsory power between actors, and structural relationships) and more diffuse forms (institutional power that favours some actors, and productive power over possession and distribution of resources).

PowerCube, John Gaventa Gaventa's PowerCube presents an operational model for the analysis of power. It depicts a dynamic relationship among three aspects of power - forms of power (based on Lukes' three faces of power) - visible, invisible and hidden power; spaces where power is exercised and claimed; and, levels of power - global, national or local.

Expressions of power, Lisa VeneKlasen et al

The four categories of power in this framework include power over (authority over others), power to (individual powers to act on something), power with (to act with others or collaborations) and power within (the ability of a person to recognise their self-knowledge, abilities or a sense of self-worth).

Cultural hegemony, Antonio Gramsci

Gramsci focuses on the concept of cultural hegemony, by which the state and the ruling classes use ideology, rather than violence, force, or economic modalities, to control and maintain capitalist power.

\section{THEORETICAL CONTRUCTS RELEVENT TO HPSR}

Feminist theories/domination

Although there are differences among various theories, feminist-informed theories broadly elevate important and previously underaddressed issues, most notably: the ways in which gender hierarchies shape health policies; what care is available; and the relationships among and between health sector employees and patients. In addition to exposing structures and manifestations of domination, feminist theories may be used as part of an approach that seeks to identify and foster empowerment and solidarity, both through research processes and results.

Critical race theory

Critical race theory originated in US law schools in the 1980s as a way to understand how the law has been used to maintain white supremacy. Concepts and methods from critical race theory, including race conscious orientation, which require specific attention be paid to racism and its interpersonal and structural drivers, have been used to explore racial inequity in the context of health and health systems.

Necropolitics Necropolitics builds on Foucault's idea of biopower as the state's ability to control and shape life, in contrast to the more traditional power of life and death over citizens. Necropolitics is the use of social and political power to control (differentially) how citizens live and die, with some (subjugated) bodies suspended between life and death, and has been used to understand inequities in health and the shortcomings of current global health governance and the pluralistic (ie, market infused or market dominated) sphere of public health.

Subaltern studies/ postcolonialism/decolonisation
Bourdieu $1990^{59}$ Shiffman $2015^{123}$

Behague et al $2008^{124}$ Hanefeld and Walt $2015^{125}$

Foucault $1978^{126}$

Dalglish et al $2017^{127}$

Sen et al $2020^{14}$

Scott et al $2017^{128}$

Barnett and Duval $2004^{60}$ Marten $2019^{129}$

Moon $2019^{22}$

Gaventa et al $2011^{46}$ Nisbett et al 2014 ${ }^{130}$

McCollum et al $2018^{131}$

Veneklasen and Miller $2002^{64}$

McCollum et al $2018^{131}$

Gramsci 199961; Worth $2002^{132}$

Morgan et al $2016^{133}$

Theobald et al $2017^{134}$

Parikh $2012^{135}$

Borrell $2018^{136}$

Hardeman et al $2020^{137}$

Mbembe $2019^{53}$

Lee $2020^{138}$

Spivak and Said $1988^{139}$

Guha $1997^{140}$

Caxaj 2015 ${ }^{141}$

Kingori and Gerrets ${ }^{142}$

McPhail-Bell et al $2013^{143144}$

Continued
Young $2014^{62}$

Sandset $2021^{57}$
Subaltern people are those who are subordinated for reasons of class, caste, gender, race, language and culture; subaltern studies centres these people and the structures of subordination. Postcolonialism was initially developed in literary theory; it is concerned with narrative and representation and how this perpetuates hegemonic forms of knowledge and power. Decolonisation refers to the social science study of the process of decolonisation, as well as to a newer movement to 'decolonize global health' (and likely other fields and disciplines). 
Table 2 Continued

Theories useful for power analysis

Key constructs/brief description

Core texts and examples

of application

OPERATIONAL PUBLIC POLICY THEORIES

Models of decision making in public policy

Various models of public policy decision making incorporate power in different ways. Buse et al, for example, list rational and incremental models of decision making, a mixed-scanning approach to decision making and the punctuated equilibrium model. Cairney et al developed a framework to study policy stability and change to explain differences among countries in tobacco control policy, as well as why policy did not reflect the public health evidence base. These approaches can be combined with other frameworks that interrogate power.

\begin{tabular}{|c|c|c|}
\hline Political-economic determinants & $\begin{array}{l}\text { Political-economic determinants of health highlight the power imbalances that emerge } \\
\text { from the interplay between macroeconomic structures, ideas and policy. }\end{array}$ & $\begin{array}{l}\text { Rushton and Williams } \\
2012^{149} \\
\text { Battams and Townsend } \\
2019^{150} \\
\text { Kentikelenis and Rochford } \\
2019^{151} \\
\text { Bump and Reich } 2013^{152}\end{array}$ \\
\hline Health and human rights & $\begin{array}{l}\text { The right to an adequate standard of living and to medical services were included in } \\
\text { the } 1948 \text { Universal Declaration of Human Rights; the right to health was included in } \\
\text { the } 1966 \text { International Covenant on Economic Social and Cultural Rights. From the } \\
\text { late } 1980 \text { s, the field of 'health and human rights' coalesced as a way of understanding } \\
\text { the human rights drivers and impacts of the HIV pandemic. Human rights provides } \\
\text { a diagnostic or descriptive framework for research on the right to health, as well as } \\
\text { solutions for how health and other government sectors should react to that research. }\end{array}$ & $\begin{array}{l}\text { Mann } 1996^{153} \\
\text { Gruskin } 2004^{154} \\
\text { Freedman } 2007^{155} \\
\text { Yamin and Norheim } 2014^{156} \\
\text { Forman } 2009^{157}\end{array}$ \\
\hline Street-level bureaucracy & $\begin{array}{l}\text { Initially developed by political scientist Michael Lipsky, the theory of street-level } \\
\text { bureaucracy is concerned with state employees who interact with citizens in the } \\
\text { everyday conduct of their tasks, such as police officers, local government officials } \\
\text { and health providers. These bureaucrats have some degree of discretion in their } \\
\text { interpretation and implementation of policies. From the perspective of community } \\
\text { members, decisions and actions taken by street-level bureaucrats constitute } \\
\text { government policy. }\end{array}$ & $\begin{array}{l}\text { Lipsky } 1980^{58} \\
\text { Erasmus } 2014^{158} \\
\text { Walker and Gilson } 2004^{159}\end{array}$ \\
\hline
\end{tabular}

HPSR, health policy and systems research.

refine a theory or produce more immediately actionable findings. A summary table of these methodologies may be found in online supplemental appendix 3 .

To further make this point, table 3 provides illustrative examples of possible combinations of research question, theory and methodology. The inclusion in the table of two research questions at each of the different levels of health policy and systems function (micro, meso and macro) is intended to demonstrate (although incompletely) the breadth of potential inquiry as well as to showcase the specificity sometimes required to enable effective theoretical and methodological linkage. A key point made clear by the repeat

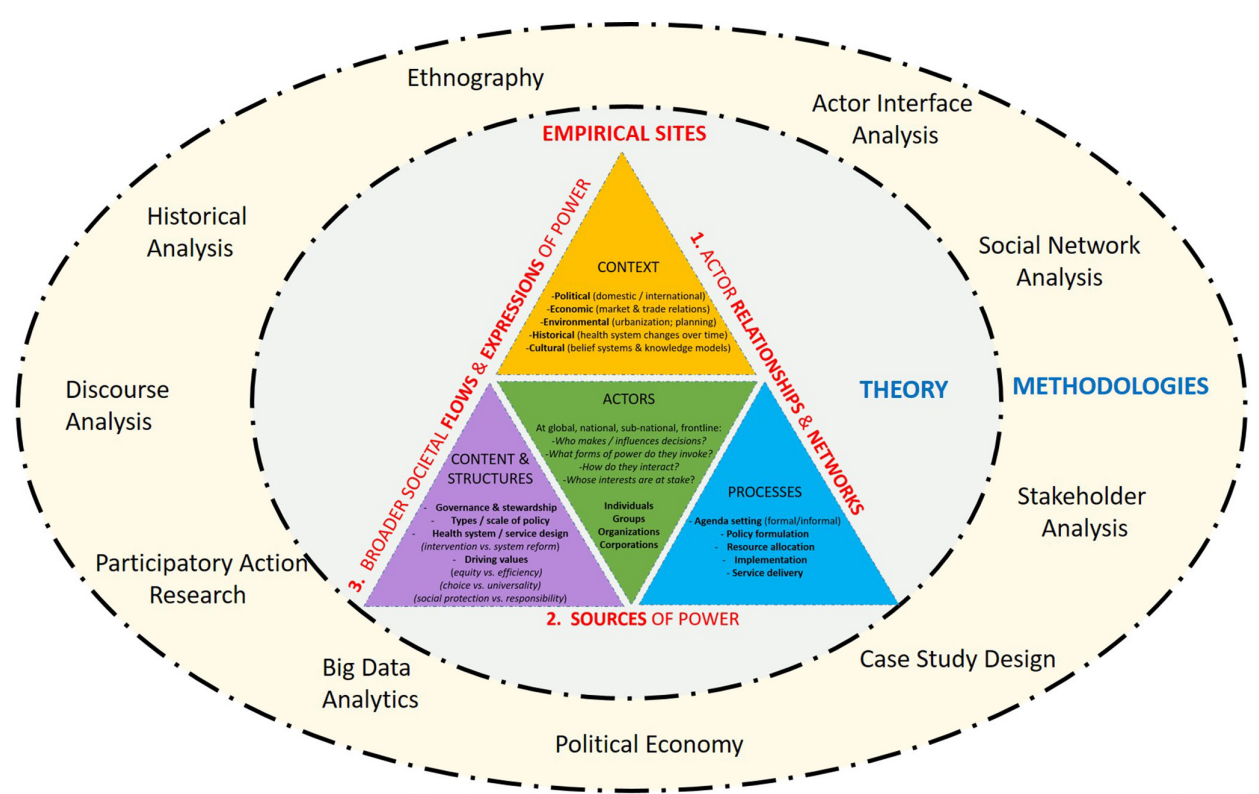

Figure 2 Linking empirical sites, theory and methodologies for research on power in health policy and systems research. 
Table 3 Illustrative combinations of theory and methodology paired with research questions on power in HPSR

$\begin{array}{llll}\begin{array}{l}\text { Socioecological } \\ \text { level }\end{array} & \text { Examples of research questions } & \begin{array}{l}\text { Examples of potentially applicable } \\ \text { theories }\end{array} & \begin{array}{l}\text { Examples of corresponding } \\ \text { methodologies }\end{array}\end{array}$

EMPIRICAL SITE 1: ACTORS AND ACTOR NETWORKS

How does the degree of participatory leadership style among hospital and district health directors affect hospital staff roles in accountability processes?

How does $X$ peer communication and Micro mentorship programme foster health advocacy and political capabilities within a racially diverse community of commercial sex workers?

In what ways do the social networks of public and private healthcare providers differ in terms of their relationships with state level health authorities and insurers? How might these differences affect the introduction of a regulatory regime for counterfeit antibiotics?

Meso

How have the formal and informal channels of in-person communication regarding the liberalised abortion law shaped how the law is interpreted and practiced by health providers in rural areas of country $X$ ?

How did civil society representatives in country $X$ leverage social and moral power conferred by their HIV status and other identities, to influence the country's proposal to the Global Fund to Fight AIDS, TB and Malaria?

Macro What attributes of social networks among representatives of large corporations involved in the production, packaging and sale of food products, Ministers of Health, and Ministers of Trade, influence the role that Countries $X, Y$ and $Z$ played in WHO discussions regarding limitations on advertising of unhealthy food?
- Weber's three sources of authority.

Lipsky's street level bureaucracy.

- Gaventa's PowerCube.

- VeneKlasen et al's expressions of power.

- Feminist theories.

- Intersectionality.

- Critical race theory.

- Subaltern theories.

- Health and human rights.

- Bourdieu's fields.

- Policy transfer.

Political systems.

Lipsky's street level bureaucracy.

Feminist theories.

Health and human rights.

Lukes' three faces of power.

Bourdieu's fields.

Foucault's power/knowledge.

Gaventa's PowerCube.

Barnett and Duvall's taxonomy of power.

- Necropolitics.

- Postcolonial theory.

- Kentikelenis and Connor's power asymmetries in global governance for health.

Rushton and Williams' frames, paradigms and power.
Social network analysis.

Historical analysis.

Actor interface analysis.

Case study.

Ethnography.

- Comparative case study.

Actor interface analysis. enquiry methods.

- Actor interface analysis.

- Case study.

- Ethnography.

- Actor interface analysis.

Case study.

Social network analysis.

- Actor interface analysis.

- Discourse analysis.

- Case study.

- Historical methods.
- Social network analysis.
In what ways does the discretionary power of frontline health workers influence the implementation of a new programme to provide home-based care for type 1 diabetes in country $Y$, and what are the determinants of how that power is exercised?

How do middle manager conceptions of biomedical expertise and primary healthcare shape the integration of community health workers into primary health centre teams?

Meso
How do political authority, financial resources, cultural capital and technical expertise shape the performance of(health governance/research funding decisions) institutions in country $X$ ?

How do conflicts of interest in the stewardship of public and private medical education shape the recruitment, distribution and competency of human resources for health in country $X$ ?
- Long's actor oriented perspective.

- Critical race theory.

Critical race theory

Lipsky's street level bureaucracy.

- Feminist approaches.

Intersectionality.

- Bourdieu's fields.

- Bourdieu's fields.

- Weber's three sources of authority.

Critical race theory.

Gaventa's power cube.

VeneKlasen et al's expressions of power.

Grindle and Thomas' policy elites.
- Ethnography.

- Case study.

- Ethnography.

Case study.

Actor interface analysis.

Historical methods.

Ethnography.

- Case study.

- Political economy.

Historical methods.

Ethnography.

- Case study.

Stakeholder analysis. 
Table 3 Continued

\begin{tabular}{|c|c|c|c|}
\hline $\begin{array}{l}\text { Socioecological } \\
\text { level }\end{array}$ & Examples of research questions & $\begin{array}{l}\text { Examples of potentially applicable } \\
\text { theories }\end{array}$ & $\begin{array}{l}\text { Examples of corresponding } \\
\text { methodologies }\end{array}$ \\
\hline \multirow[t]{2}{*}{ Macro } & $\begin{array}{l}\text { How does the presence of supra-state, } \\
\text { global trade institutions - such as } \\
\text { the WTO or International Investment } \\
\text { Agreements (IIAs)-differentially influence } \\
\text { governments' capacity to control their } \\
\text { health policy and programming? }\end{array}$ & $\begin{array}{l}\text { Barnett and Duvall's taxonomy of } \\
\text { power. } \\
\text { Gramsci's cultural hegemony. } \\
\text { Foucault's power/knowledge. }\end{array}$ & $\begin{array}{l}\text { Political economy. } \\
\text { Discourse analysis. } \\
\text { Case study research. }\end{array}$ \\
\hline & $\begin{array}{l}\text { What institutional and legal mechanisms } \\
\text { can regulate tech companies developing } \\
\text { artificial intelligence }(\mathrm{Al}) \text { applications that } \\
\text { collect and analyse real-time health data? }\end{array}$ & $\begin{array}{l}\text { New institutionalism. } \\
\text { Rushton and Williams' frames, } \\
\text { paradigms and power. } \\
\text { Health and human rights. }\end{array}$ & $\begin{array}{l}\text { Political economy. } \\
\text { Discourse analysis. } \\
\text { Case study research. }\end{array}$ \\
\hline
\end{tabular}

\section{EMPIRICAL SITE 3: SOCIETAL FLOWS AND EXPRESSIONS OF POWER}

How do socioeconomic factors such as class, religion, ethnicity, gender and caste interact to shape the relative power dynamics of local-level health planning committees?

How do the relationships between health workers, their representative associations/ unions and local politicians shape the practice of corruption, fraud and abuse at the facility-level, block-level and districtlevel?

How do shifts in political parties or political regimes change explicit or implicit values driving sexual and reproductive rights and health policy?

Meso

How have colonial-era institutions, legislation and bureaucratic structures influenced health workforce policy at the national level in country $Y$ ?

How do multinational corporations strategise at the global and nationallevel to influence health policy in their interest? What countervailing forces or powers exist or form in opposition to this influence?

Macro

How is the foreign policy and geopolitical strategy of country ' $Z$ " influencing the distribution of its COVID-19 vaccine supplies to other countries?
- VeneKlasen et al's expressions of power

- Gaventa's PowerCube.

- Critical race theory.

- Feminist theories/domination.

Intersectionality.

Ostrom's institutions for collective action.

- Street-level bureaucracy.

Long's actor oriented perspective.

- Ethnography.

- Case study research.

- Participatory action research.

- Grindle and Thomas' policy elites.

- Gramsci's cultural hegemony.

- Necropolitics.

- Health and human rights.

- Max Weber's three sources of authority.

- Foucault's power/knowledge.

- Subaltern studies.

- Postcolonialism.

- Rushton and Williams' frames, paradigms and power.

- Kentikelenis and Connor's power asymmetries in global governance for health.

- Gramsci's cultural hegemony.

$>$ Policy transfer.

Barnett and Duvall's taxonomy of power.

- Rushton and Williams' frames, paradigms and power.

- Kentikelenis and Connor's power asymmetries in global governance for health. listings of theories and methodologies across the various questions in table 3 is that there are many valid combinations of theories and methodologies.

\section{USEFUL METHODOLOGIES FOR EMPIRICAL SITE 1: ACTOR RELATIONSHIPS AND NETWORKS}

Stakeholder analysis is an actor-oriented methodology useful for examining the power differentials of key policy and health system actors, ranging from frontline healthcare workers to national level policy makers. ${ }^{20}$ Stakeholder analysis is most commonly used prospectively, as a tool for researchers and practitioners to understand the feasibility of a given policy and to develop responses to likely challenges in implementing that policy. ${ }^{66}$ Stakeholder analysis can also be used retrospectively, as a stand-alone study or in combination with political economy and case study approaches. Stakeholder analysis is also commonly used to consider sources of power, described in further detail below.

Actor interface analysis focuses on understanding individual actors (rather than organisations), examines policy through the lens of power struggles between individuals and explores how this behaviour is embedded in actors' lived experiences and values, called actor lifeworlds. ${ }^{6768}$ When used to study health policy, actor interface analysis examines how interactions among different actors shape the implementation and outcomes of the policy. Where actors interact, collaboration, contestation or resistance can be identified and analysed. This methodology brings an actor-centric lens 
to the study of power in policy implementation as compared with other (more institutionally focused) methodologies and helps to examine how policy-related decisions and action are shaped by the actors themselves. ${ }^{6769} 70$

Social network analysis is the quantitative study of relationship patterns among actors, with actors being broadly defined to potentially include people, groups or organisations. ${ }^{71} 72$ This methodology draws from sociology and mathematical foundations of graph theory to illuminate how the nature of actors and ties (eg, number, strength and type of tie, such as friendship, supervisory relationship and whether information, resources or beliefs were shared) enable expressions and tools of power (eg, money, pressure, influence and knowledge) to be concentrated, spread or blocked..$^{73}$ In the field of HPSR, social network analysis can be used to analyse the health system structure as it functions, including through informal personal relationships, rather than as it is formally defined. ${ }^{74}$ This can inform policy makers about how ties among actors can influence the diffusion and implementation of health reforms and programmes; how social networks influence governance and financing structures; as well as informing the public about how policy makers may be using power to include or exclude certain actors. ${ }^{71} 7576$

\section{USEFUL METHODOLOGIES FOR EMPIRICAL SITE 2: SOURCES OF POWER}

Case study design is a form of empirical inquiry characterised by an 'intense focus on a single phenomenon within its real-life context ${ }^{77}$ and is particularly useful in situations where boundaries between the phenomenon of interest and the context are blurred. In relation to power in HPSR, case study research has most commonly been used to produce exploratory and explanatory accounts focusing on different actors' expressions of power (formal and informal, overt and covert) to answer 'how?' and 'why?' certain health policy or system features exist and to assess efforts to change power dynamics. ${ }^{20}{ }^{78}$ By combining an interpretivist (seeking to understand individual and shared social meanings) and critical (questioning one's own and others' assumptions) analytical approach, researchers may use this methodology to consciously account for the ways in which broader social and political environments influence both macropower and micropower dynamics. ${ }^{79}{ }^{80}$ Comparative case studies can be used for theory building or theory testing.

Political economy analysis is a methodology used to identify and describe structures such as government and the law; resources (labour, capital, trade and production) and how they are distributed and contested in different country and sector contexts, and the resulting implications for policy and indicators of well-being. ${ }^{81}$ Of relevance to HPSR, political economy can draw on both quantitative and qualitative methods to explore the nature of the political landscape through mapping the power and position of key actors. Political economy can also explore how the distribution of resources influence relationships and through this the feasibility and trajectory of policy reform over time ${ }^{8182}$ Reflecting their roots in the comparatively more positivist paradigms of political science and economics, these methodologies have been used for purposes of explanation and hypothesis testing in HSPR, including in the context of evaluations and policy design. Consistent with HPSR's multidisciplinary orientation, political economy methodologies can nonetheless be developed and deployed in a way that accommodates-or even centres-interpretive goals.

Big data analytics examines high volume, biological, clinical, environmental and behavioural information collected from single individuals to large cohorts at one or several time points. ${ }^{83}$ Big data analytics can uncover patterns in health outcomes and health behaviours ${ }^{84}$; health policy (eg, resourcing and implementation fidelity) ${ }^{85}$; and health system function (eg, provider behaviours) ${ }^{867}$ When applied in conjunction with a power lens, big data analytics can reveal importantand often masked trends or patterned experiences, prompting further explanatory work or evaluative action. ${ }^{88}$ For example, Yu et a $\ell^{99}$ use big data analytics to explore the influence of private medical providers in promoting unnecessary medical interventions. ${ }^{89}$ Big data analytics may also help identify systemic issues such as discrimination, information asymmetry and patient-provider dynamics and their influence on care quality. Nonetheless, given its volume as well as its potential interest to profit seeking entities, big data presents unique challenges for ethics, boundaries and reflexivity. Researchers should carefully consider the potential misuses of the data, the extent to which the data accurately represents the factors of interest (construct validity) and which individuals and groups are overlooked in analyses that focus on the mean (or median) ${ }^{90}$

\section{USEFUL METHODOLOGIES FOR EMPIRICAL SITE 3: SOCIETAL FLOWS AND EXPRESSIONS OF POWER}

Discourse analysis entails close examination of the use of language in texts (such as laws, policies, strategy documents or news media articles) and oral communication (such as transcribed interviews, debates or speeches) to describe the ways in which communicative acts construct shared understandings of what is normal ${ }^{91}{ }^{92}$ and what is possible, legitimate, or true.$^{63}$ Discourse analysis should include the study of what is present in the text, as well as what is assumed or ignored, shedding light on often unacknowledged material asymmetries and social hierarchies that pervade health policy-making at all levels. ${ }^{93}{ }^{94}$ In this way, discourse analysis can expose and problematise dominant paradigms in global and domestic health policy-making, such as the ways that standard epidemiological risk factors obscure structural inequities, ${ }^{95}$ the assumption that the private sector will act in the public interest ${ }^{96}$ or that a primary function of government reproductive health programmes is to decrease the fertility rate, rather than enable reproductive autonomy. ${ }^{97}$

Ethnographers seek to understand how humans in groups interact, behave and perceive, and how meaning and value are established. Ethnography can build rich and holistic understanding of people's perspectives, practices and cultural context ${ }^{98}$ and focuses on depth over breadth, immersive observation in natural settings (eg, non-experimental 
conditions), exploratory (rather than hypothesis testing) research and describing the meaning and function of human action in context. ${ }^{99} 100$ While ethnography has its origins in colonial conceptions of 'culture' and colonial motivations to study them and has thus been frequently used to 'study down', ${ }^{101}$ ethnography has also been employed to research 'up, down and sideways'. ${ }^{102}$ This includes work focusing on institutions and politics, political legitimacy, moral universes, tacit knowledge and discourses to provide insight into how power is constructed, solidified and wielded within and beyond health systems, ${ }^{103} 104$ the development and normalisation of certain forms of knowledge ${ }^{105}$ and the implicit or explicit privilege or denigration of individuals or marginalised groups accessing healthcare. ${ }^{106}$

Participatory action research (PAR) seeks to build new understandings of power while also changing power relations. PAR seeks to shift control over the construction of knowledge and truth from the historically privileged to the historically marginalised ${ }^{107} 108$ and increase participant understandings of injustice (conscientisation) ${ }^{109}$ in order to build solidarity ${ }^{110}$ and transform systems and institutions. PAR explores and recognises different sources of power (eg, social position, nationality and cultural knowledge) and applications of power (eg, via citizen-led collective action ${ }^{111}$ ). This research methodology typically entails the use of tools, such as community meetings, resource mapping, problem identification, visioning and diaries that draw out the priorities and perspectives of the communities participating, rather than reflecting a priori theory. It is apt for exploratory questions, as well as for bringing stakeholders together to cocreate solutions to health systems challenges. ${ }^{112}$

Historical research aims to generate or regenerate explanatory narratives relating to past events, places or people. Historical evidence includes visual, audio and text-based materials (archival material, communications, policy documents and project reports) and first-person accounts (oral histories). The study of history can illuminate broad powerrelated themes that continue to be relevant, such as the interface between individual liberty and domestic governmental health objectives ${ }^{113}$; medical experimentation, social control and scientific racism ${ }^{114} 115$; corporate profit making, governmental interference and population health ${ }^{116}$; and global health as a vehicle for state-craft, diplomacy, population control and Western-centric conceptions of charity. ${ }^{87117-119}$ Historical studies also offer broader explanatory value as 'cases' for the development of theory related to power ${ }^{27} 28$ and as case studies for contemporary policy debates. Insofar as traditional historical approaches can privilege written work, it may omit the perspectives of historically oppressed groups. To combat this tendency, alternative methods such as participatory oral historical or community-based sourcing of visual, audio and text-based records not located in 'official' repositories open up alternative analytical possibilities.

\section{CONCLUSION}

More research on power in health policy and systems is needed. Linking empirical inquiry with theory and methodologies, with attention to positionality strengthens the rigour of such research and can help improve the depth and breadth of knowledge regarding root causes of inequities in health. This paper guides readers through the multiple stages involved, and a range of theories and methodologies that may be used, in developing a study focused on power in health policy and systems. It also seeks to push the HPSR field to challenge the political economy of research and destabilise hierarchies of knowledge through greater honesty about how power dynamics influence the research endeavour itself. Through the analysis of power in health policies and systems, we encourage researchers to expand the boundaries of how we may address inequities of health, to surface new insights, theories and approaches pertaining to power and, ultimately, to contribute to a more just world.

\section{Author affiliations}

${ }^{1}$ College of Public Health Medical and Veterinary Sciences, James Cook University, Townsville, Queensland, Australia

${ }^{2}$ Nossal Institute for Global Health, University of Melbourne, Melbourne, Victoria, Australia

${ }^{3}$ Independent Consultant, Brooklyn, New York, USA

${ }^{4}$ School of Public Policy and Global Affairs and School of Population and Public Health, University of British Columbia, Vancouver, British Columbia, Canada

${ }^{5}$ Department of International Health, Johns Hopkins University Bloomberg School of Public Health, Baltimore, Maryland, USA

${ }^{6}$ Independent Consultant, Toronto, Ontario, Canada

${ }^{7}$ Institute for Global Health, University College London, London, UK

${ }^{8}$ Health and Nutrition Cluster, Institute of Development Studies, Brighton, UK

${ }^{9}$ Jawaharlal Institute of Postgraduate Medical Education and Research, Puducherry,

Tamil Nadu, India

${ }^{10}$ Azim Premji University, Bangalore, Karnataka, India

${ }^{11}$ Independent Consultant, New Delhi, India

${ }^{12}$ Oxford Policy Management, New Dehli, India

${ }^{13}$ Alliance for Health Policy and Systems Research, WHO, Geneva, Switzerland

${ }^{14}$ Independent Consultant, Geneva, Switzerland

${ }^{15}$ Society for Community Health Awareness Research and Action, Bangalore, Karnataka, India

${ }^{16}$ Alliance for Improving Health Outcomes Inc, Quezon City, Philippines

${ }^{17}$ Independent Consultant, Raipur, India

Twitter Stephanie M Topp @globalstopp, Marta Schaaf @martaschaaf, Veena Sriram @veena_sriram, Kerry Scott @kerfully, Sarah L Dalglish @Sarah_Dlish, Sumegha Asthana @sumeghaasthana, Rakesh Parashar@Ra_Parashar, Robert Marten @martenrobert, Emma Sacks @ersacks and Katherine Ann V Reyes @DrKathyReyes

Acknowledgements Walter Flores was part of discussions during which this paper was conceived. We would like to thank members of the Social Science Approaches for Research and Engagement in Health Policy and Systems (SHAPES) Thematic Working Group of Health Systems Global for their feedback on the initial concept note. We would like to thank Prachi Sanghavi (University of Chicago) and Michelle Friedner (University of Chicago) for their review of sections of the paper during development.

Contributors SMT, MS, VS and KS conceived of the paper. SMT, MS and VS led design of figures 1 and 2 and table 2 and coordinated drafting of different components of the paper. All authors contributed to methodological synthesis and drafting of text and all provided critical input to multiple drafts. SMT, MS and VS act as guarantor to this article.

Funding This collaborative project received no special funding. SMT holds a NHMRC Investigator Award (2020-24) GNT1173004.

Competing interests None declared.

Patient consent for publication Not applicable. 
Provenance and peer review Not commissioned; externally peer reviewed.

All data relevant to the study are included in the article or uploaded as supplementary information

Supplemental material This content has been supplied by the author(s). It has not been vetted by BMJ Publishing Group Limited (BMJ) and may not have been peer-reviewed. Any opinions or recommendations discussed are solely those of the author(s) and are not endorsed by BMJ. BMJ disclaims all liability and responsibility arising from any reliance placed on the content. Where the content includes any translated material, BMJ does not warrant the accuracy and reliability of the translations (including but not limited to local regulations, clinical guidelines, terminology, drug names and drug dosages), and is not responsible for any error and/or omissions arising from translation and adaptation or otherwise.

Open access This is an open access article distributed in accordance with the Creative Commons Attribution Non Commercial (CC BY-NC 4.0) license, which permits others to distribute, remix, adapt, build upon this work non-commercially, and license their derivative works on different terms, provided the original work is properly cited, appropriate credit is given, any changes made indicated, and the use is non-commercial. See: http://creativecommons.org/licenses/by-nc/4.0/.

\section{ORCID iDs}

Stephanie M Topp http://orcid.org/0000-0002-3448-7983

Marta Schaaf http://orcid.org/0000-0002-7616-5966

Kerry Scott http://orcid.org/0000-0003-3597-9637

Sarah L Dalglish http://orcid.org/0000-0002-7218-5193

Erica Marie Nelson http://orcid.org/0000-0001-9161-4814

Rajasulochana SR http://orcid.org/0000-0003-3597-4991

Arima Mishra http://orcid.org/0000-0001-7218-932

Sumegha Asthana http://orcid.org/0000-0003-4186-2136

Robert Marten http://orcid.org/0000-0002-2416-2309

Emma Sacks http://orcid.org/0000-0003-0743-7208

Katherine Ann V Reyes http://orcid.org/0000-0002-2903-6571

\section{REFERENCES}

1 OED. OED, Power. In: Oxford English dictionary. UK: Oxford, 2021.

2 Shawar YR, Ruger JP. The politics of global health inequalities: approaches to studying the role of power. In: The oxford handbook of global health politics. Oxford, UK: Oxford University Press, 2020.

3 World Health Organization. Everybody's business: strengthening health systems to improve health outcomes: WHO's framework for action. Geneva, Switzerland: World Health Organization, 2007.

4 Gorsky M, Sirrs C. From «planning» to "systems analysis»: Health services strengthening at the World Health Organisation, 19521975. Dynamis 2019;39:205-33.

5 Manton J, Gorsky M. Health planning in 1960s Africa: international health organisations and the post-colonial state. Med Hist 2018;62:425-48.

6 Sheikh K, George A, Gilson L. People-centred science: strengthening the practice of health policy and systems research Health Res Policy Syst 2014;12:19.

7 Gore R, Parker R. Analysing power and politics in health policies and systems. Glob Public Health 2019;14:481-8.

8 Packard R. A history of global health: interventions into the lives of other peoples. Baltimore, MD: Johns Hopkins University Press, 2016.

9 Harris P, Baum F, Friel S, et al. A glossary of theories for understanding power and policy for health equity. $J$ Epidemiol Community Health 2020;74:jech-2019-213692-52.

10 Crane BB, Dusenberry J. Power and politics in international funding for reproductive health: the US global Gag rule. Reprod Health Matters 2004;12:128-37.

11 de Lacy-Vawdon C, Livingstone C. Defining the commercial determinants of health: a systematic review. BMC Public Health 2020;20:1022

12 Pfeiffer J, Nichter M, Critical Anthropology of Global Health Special Interest Group. What can critical medical anthropology contribute to global health? A health systems perspective. Med Anthropol $Q$ 2008;22:410-5.

13 Rizvi SS, Douglas R, Williams OD, et al. The political economy of universal health coverage: a systematic narrative review. Health Policy Plan 2020;35:364-72.

14 Sen G, lyer A, Chattopadhyay S, et al. When accountability meets power: realizing sexual and reproductive health and rights. Int $J$ Equity Health 2020;19:111.

15 Shiffman J. Knowledge, moral claims and the exercise of power in global health. Int J Health Policy Manag 2014;3:297-9.
16 Sriram V, Topp SM, Schaaf M, et al. 10 best resources on power in health policy and systems in low- and middle-income countries. Health Policy Plan 2018;33:611-21.

17 Inguane CA. Critical perspectives on global health partnerships in Africa. Medicine Anthropology Theory 2018;5:p. ii-vi.

18 Mumtaz Z, Ferguson A, Bhatti A, et al. Learning from failure? political expediency, evidence, and inaction in global maternal health. Soc Sci Med 2019;232:427-31.

19 Erasmus E, Gilson L. How to start thinking about investigating power in the organizational settings of policy implementation. Health Policy Plan 2008;23:361-8.

20 Gilson L, Orgill M, Shroff Z, eds. A health policy analysis reader: the politics of policy change in low- and middle-income countries. Geneva, Switzerland: Alliance for Health Policy and Systems Research and World Health Organization, 2018.

21 Loewenson R, Laurell A, Hogstedt C, eds. Participatory action research in health systems: a methods reader. Harare, Zimbabwe: TARSC, AHPSR, WHO, IDRC Canada, EQUINET, 2014.

22 Moon S. Power in global governance: an expanded typology from global health. Global Health 2019;15:74.

23 Dalglish SL, Khalid H, McMahon SA. Document analysis in health policy research: the read approach. Health Policy Plan 2021;35:1424-31.

24 Gilson L. Health policy and systems research: a methodology reader. Geneva, Switzerland: World Health Organization, 2012.

25 Walt G, Gilson L. Reforming the health sector in developing countries: the central role of policy analysis. Health Policy Plan 1994;9:353-70.

26 Agyepong IA. Universal health coverage: breakthrough or great white elephant? Lancet 2018;392:2229-36.

27 Woolcock M, Szreter S, Rao V. How and why history matters for development policy. In: History, historians and development policy. Manchester University Press, 2020.

28 Szreter S. The Importance of Social Intervention in Britain's Mortality Decline $c$.1850-1914: a Re-interpretation of the Role of Public Health. Social History of Medicine 1988;1:1-38.

29 Anderson W. Making global health history: the postcolonial worldliness of biomedicine. Social History of Medicine 2014;27:372-84.

30 Sivaramakrishnan K. Old Potions. New bottles: Recasting Indigenous medicine in colonial Punjab, 1945. Orient Longman, 2006.

31 Cueto M, Palmer S. Medicine and public health in Latin America: a history. New York: Cambridge University Press, 2015.

32 Stepan N. The hour of eugenics: race, gender, and nation in Latin America. Ithaca, NY: Cornell University Press, 1991.

33 Adams V. Metrics of the global sovereign: numbers and stories in global health. In: Metrics: what counts in global health. Durham, NC: Duke University Press, 2016.

34 Parkhurst $\mathrm{J}$. The politics of evidence: from evidence-based policy to the good governance of evidence. In: Routledge studies in governance and public policy. Abingdon, Oxon, UK.: Routledge, 2017.

35 Abimbola S. The uses of knowledge in global health. BMJ Glob Health 2021;6:e005802.

36 Storeng KT, Mishra A. Introduction. politics and practices of global health: critical ethnographies of health systems. Glob Public Health 2014;9:858-64

37 Abimbola S. The foreign gaze: authorship in academic global health. BMJ Glob Health 2019:4:e002068.

38 Datta R. Decolonizing both researcher and research and its effectiveness in Indigenous research. Res Ethics 2018;14:1-24.

39 Sultana F. Reflexivity, positionality and participatory ethics: negotiating fieldwork dilemmas in international research. ACME 2007;6:374-85 https://www.researchgate.net/publication/ 228497658_Reflexivity_positionality_and_participatory_ethics_ Negotiating fieldwork dilemmas in international research

40 Citrin D, Mehanni S, Acharya B, et al. Power, potential, and pitfalls in global health academic partnerships: review and reflections on an approach in Nepal. Glob Health Action 2017;10:1367161.

41 Mafuta EM, Dieleman MA, Essink L, et al. Participatory approach to design social accountability interventions to improve maternal health services: a case study from the democratic republic of the Congo. Glob Health Res Policy 2017;2:p. 4.

42 Keikelame MJ, Swartz L. Decolonising research methodologies: lessons from a qualitative research project, Cape town, South Africa. Glob Health Action 2019:12:1561175.

43 Pratt B. Social justice and the ethical goals of community engagement in global health research. $J$ Bioeth Inq 2019;16:571-86. 
44 Jumbam DT. How (not) to write about global health. BMJ Glob Health 2020;5.

45 Crotty M. Foundations of social research: meaning and perspective in the research process. SAGE Publications, 1998.

46 Gaventa J, Pettit J, Cornish L. Power pack, understanding power for social change. Sussex, UK: Institute for Developmental Studies, 2011.

47 Weber M. The meaning of discipline. In: Max weber: essays in sociology. Imprint Routledge, 1948.

48 Ford CL, Airhihenbuwa CO. Commentary: just what is critical race theory and what's it doing in a progressive field like public health? Ethn Dis 2018;28:223-30.

49 Müller A. Beyond 'invisibility': queer intelligibility and symbolic annihilation in healthcare. Cult Health Sex 2018;20:14-27.

50 Sharma M. Applying feminist theory to medical education. Lancet 2019;393:570-8.

51 Crenshaw K. Mapping the margins: intersectionality, identity politics, and violence against women of color. Stanford Law Rev 1991;43:1241-99.

52 Larson E, George A, Morgan R, et al. 10 best resources on... intersectionality with an emphasis on low- and middle-income countries. Health Policy Plan 2016;31:964-9.

53 Mbembe A. Necropolitics. Durham, NC: Duke University Press, 2019.

54 Hankivsky O, Grace D, Hunting G, et al. An intersectionality-based policy analysis framework: critical reflections on a methodology for advancing equity. Int J Equity Health 2014;13:119.

55 Kapilashrami A, Hill S, Meer N. What can health inequalities researchers learn from an intersectionality perspective? understanding social dynamics with an inter-categorical approach? Soc Theory Health 2015;13:288-307.

56 Decolonising COVID-19. Lancet Glob Health 2020;8:e612.

57 Sandset T. The necropolitics of COVID-19: race, class and slow death in an ongoing pandemic. Glob Public Health 2021;16:1411-23.

58 Lipsky M. Street-Level bureaucracy: dilemmas of the individual in public services. New York: Russell Sage Foundation, 1980.

59 Bourdieu P. The logic of practice. Stanford University Press, 1990.

60 Barnett M, Duval R. Power in global governance. Cambridge: Cambridge University Press, 2004.

61 Gramsci A. Selections from the prison notebooks. London, UK: The Electric Book Company, 1999.

62 Young S. Changing the world: discourse, politics and the feminist movement. Routledge, 2014.

63 Foucault M. The archaeology of knowledge and the discourse on language. In: Pantheon books, 1972.

64 Veneklasen L, Miller V. A new weave of power, people \& politics: the action guide for advocacy and citizen participation. Oklahoma City, OK: World Neighbors, 2002.

65 Lukes S. Power: a radical view. Macmillan International Higher Education, 2004

66 Abiiro GA, McIntyre D. Universal financial protection through national health insurance: a stakeholder analysis of the proposed one-time premium payment policy in Ghana. Health Policy Plan 2013;28:263-78.

67 Long N. Development sociology: actor perspectives. London, UK: Routledge, 2001.

68 Schutz A. The problem of social reality. The Hague: Mijhoff, 1962.

69 Lehmann U, Gilson L. Actor interfaces and practices of power in a community health worker programme: a South African study of unintended policy outcomes. Health Policy Plan 2013;28:358-66.

70 Parashar R, Gawde N, Gilson L. Application of "actor interface analysis" to examine practices of power in health policy implementation: an interpretive synthesis and guiding steps. Int $J$ Health Policy Manag 2020. doi:10.34172/ijhpm.2020.191. [Epub ahead of print: 13 Oct 2020].

71 Blanchet K, James P. How to do (or not to do) a social network analysis in health systems research. Health Policy Plan 2012;27:438-46.

72 Hawe P, Webster C, Shiell A. A glossary of terms for navigating the field of social network analysis. $J$ Epidemiol Community Health 2004;58:971-5.

73 Borgatti SP, Mehra A, Brass DJ, et al. Network analysis in the social sciences. Science 2009;323:892-5.

74 Oliver K. Evaluating power, influence and evidence-use in public health policy-making: a social network analysis, in school of medicine. University of Manchester, 2012.

75 Etemadi M, Gorji HA, Kangarani HM, et al. Power structure among the actors of financial support to the poor to access health services: social network analysis approach. Soc Sci Med 2017; 195:1-11.
76 Wang G-X. Policy network mapping of the universal health care reform in Taiwan: an application of social network analysis. J Asian Public Policy 2013;6:313-34.

77 Yin R. Case study research design and methods. 5 edn. SAGE Publications, 2014

78 Shiffman J, Smith S. Generation of political priority for global health initiatives: a framework and case study of maternal mortality. Lancet 2007;370:1370-9.

79 Doolin B. Power and resistance in the implementation of a medical management information system. Information Systems Journal 2004;14:343-62.

80 Rotarou ES, Sakellariou D. Neoliberal reforms in health systems and the construction of long-lasting inequalities in health care: a case study from Chile. Health Policy 2017;121:495-503.

81 Reich MR. Political economy analysis for health. Bull World Health Organ 2019;97:514

82 Collinson S. Power, livelihoods and conflict: case studies in political economy analysis for humanitarian action, overseas development Institute. London, UK, 2003.

83 Auffray C, Balling R, Barroso I, et al. Making sense of big data in health research: towards an EU action plan. Genome Med 2016;8:71.

84 OECD. Unleashing the power of big data for alzheimer's disease and dementia research: main points of the OECD expert consultation on unlocking global collaboration to accelerate innovation for alzheimer's disease and dementia. OECD Digital Economy Papers 2014.

85 Schintler LA, Kulkarni R. Big data for policy analysis: the good, the bad, and the ugly. Rev Policy Res 2014;31:343-8.

86 Pastorino R, De Vito C, Migliara G, et al. Benefits and challenges of big data in healthcare: an overview of the European initiatives. Eur $J$ Public Health 2019;29:23-7.

87 Shafqat S, Kishwer S, Rasool RU, et al. Big data analytics enhanced healthcare systems: a review. J Supercomput 2020;76:1754-99.

88 Kolkman D. The usefulness of algorithmic models in policy making. Gov Inf Q 2020;37:101488.

89 Yu N, Atteberry P, Bach P. Spending on prescription drugs in the US: where does all the money go? Health Affairs Blog 2018. URL.

90 Vayena E, Dzenowagis J, Brownstein JS, et al. Policy implications of big data in the health sector. Bull World Health Organ 2018;96:66-8

91 Sacks HJefferson G, Schegloff E, eds. Lectures on conversation. vol 1 and 2. Cambridge: Blackwell's, 1995.

92 Steel EJ. The duplicity of choice and empowerment: disability rights diluted in australia's policies on assistive technology. Societies 2019;9:39.

93 Sieleunou I, Turcotte-Tremblay A-M, Fotso J-CT, et al. Setting performance-based financing in the health sector agenda: a case study in Cameroon. Global Health 2017;13:p. 52.

94 Yazdannik A, Yousefy A, Mohammadi S. Discourse analysis: a useful methodology for health-care system researches. J Educ Health Promot 2017;6:111.

95 Boyd R, Lindo E, Weeks L. On racism: a new standard for publishing on racial health inequities. Health Affairs Blog, 2020.

96 Gideon J, Unterhalter E. Exploring public private partnerships in health and education: a critique. Journal of International and Comparative Social Policy 2017;33:136-41.

97 Connelly M, Connelly MJ. Fatal misconception: the struggle to control world population. Cambridge, MA: Harvard University Press, 2009.

98 Hammersley M, Atkinson P. Ethnography: principles in practice. Psychology Press, 1995.

99 Agar MH. Ethnography: an overview. Subst Use Misuse 1997;32:1155-73.

100 Creswell J, Poth C. Qualitative inquiry and research design: choosing among five approaches. 4 edn. SAGE Publications, 2017.

101 Nyoka B. Bernard Magubane's critique of anthropology in southern Africa: an introductory essay. Journal of Contemporary African Studies 2019;37:169-90.

102 Stryker R, González R, eds. Up, down, and sideways: anthropologists trace the pathways of power. New York: Berghahn, 2014.

103 Hagene T. The power of ethnography: a useful approach to researching politics. Forum Dev Stud 2018;45:305-25.

104 Mishra A, Nambiar D. On the unraveling of 'revitalization of local health traditions' in India: an ethnographic inquiry. Int $J$ Equity Health 2018;17:175.

105 Jain S, Jadhav S. Pills that swallow policy: clinical ethnography of a community mental health program in northern India. Transcult Psychiatry 2009;46:60-85. 
106 Spangler SA. "To open oneself is a poor woman's trouble": embodied inequality and childbirth in South-Central Tanzania. Med Anthropol Q 2011;25:479-98.

107 Aryeetey GC, Jehu-Appiah C, Kotoh AM, et al. Community concepts of poverty: an application to premium exemptions in Ghana's National health insurance scheme. Global Health 2013;9:12.

108 Mathias K, Pillai P, Gaitonde R, et al. Co-production of a pictorial recovery tool for people with psycho-social disability informed by a participatory action research approach-a qualitative study set in India. Health Promot Int 2020;35:486-99.

109 Freire P. Education for critical consciousness. London, UK: Continuum, 1974.

110 Minkler M. Using participatory action research to build healthy communities. Public Health Rep 2000;115:191-7.

111 Hernández A, Hurtig A-K, Goicolea I, et al. Building collective power in citizen-led initiatives for health accountability in Guatemala: the role of networks. BMC Health Serv Res 2020;20:416.

112 Ozano K, Dean L, Adekeye O, et al. Guiding principles for quality, ethical standards and ongoing learning in implementation research: multicountry learnings from participatory action research to strengthen health systems. Health Policy Plan 2020;35:ii137-49.

113 Colgrove J. Public health Chronicles. Public Health Rep 2004;119:506-9.

114 Gutiérrez ER, Fuentes L. Population control by sterilization: the cases of Puerto Rican and Mexican-Origin women in the United States. Latino(a) Research Review 2009;7:85-100.

115 Reverby S. Tuskegee's truths: rethinking the Tuskegee syphilis study. UNC Press Books, 2012.

116 Reubi D, Berridge V. The Internationalisation of tobacco control, 1950-2010. Med Hist 2016;60:453-72.

117 Birn A-E. Backstage: the relationship between the rockefeller foundation and the world Health organization, part I: 1940s-1960s. Public Health 2014;128:129-40.

118 Chorev N. The world Health organization between North and South. Ithaca, NY: Cornell University Press, 2012.

119 Quevedo Velez E. La salud pública en Colombia: Seis siglos entre El interes Internacional Y El desinterés nacional. Revista del Colegio Mayor de Nuestra Señora del Rosari 2001;95:5-29.

120 Buse K, Hawkes S. Health post-2015: evidence and power. Lancet 2014;383:678-9.

121 Reynolds L. Not up for discussion: applying lukes' power model to the study of health system corruption comment on "we need to talk about corruption in health systems". Int J Health Policy Manag 2019;8:723-6.

122 Sriram V, Baru R, Hyder AA, et al. Bureaucracies and power: examining the medical Council of India and the development of emergency medicine in India. Soc Sci Med 2020;256:113038.

123 Shiffman J. Global health as a field of power relations: a response to recent commentaries. Int J Health Policy Manag 2015;4:497-9.

124 Béhague DP, Kanhonou LG, Filippi V, et al. Pierre Bourdieu and transformative agency: a study of how patients in Benin negotiate blame and accountability in the context of severe obstetric events. Sociol Health IIIn 2008;30:489-510.

125 Hanefeld J, Walt G. Knowledge and networks - key sources of power in global health: Comment on "Knowledge, moral claims and the exercise of power in global health". Int J Health Policy Manag 2015;4:119-21.

126 Foucault M. An Introdcution. In: History of sexuality. New York: Random House, 1978.

127 Dalglish SL, Rodríguez DC, Harouna A, et al. Knowledge and power in policy-making for child survival in niger. Soc Sci Med 2017;177:150-7.

128 Scott K, George AS, Harvey SA, et al. Negotiating power relations, gender equality, and collective agency: are village health committees transformative social spaces in northern India? Int $J$ Equity Health 2017;16:84.

129 Marten R. How states exerted power to create the millennium development goals and how this shaped the global health agenda: lessons for the sustainable development goals and the future of global health. Glob Public Health 2019;14:584-99.

130 Nisbett N, Gillespie S, Haddad L, et al. Why worry about the politics of childhood undernutrition? World Dev 2014;64:420-33.

131 McCollum R, Taegtmeyer M, Otiso L, et al. "Sometimes it is difficult for us to stand up and change this": an analysis of power within priority-setting for health following devolution in Kenya. BMC Health Serv Res 2018:18:906.

132 Worth $\mathrm{O}$. Health for all? towards a neo-gramscian critique of the WHO. In: Critical perspectives on international political economy. London: Palgrave Macmillan, 2002: 139-58.
133 Morgan R, George A, Ssali S, et al. How to do (or not to do)... gender analysis in health systems research. Health Policy Plan 2016;31:1069-78.

134 Theobald S, Morgan R, Hawkins K, et al. The importance of gender analysis in research for health systems strengthening. Health Policy Plan 2017;32:v1-3.

135 Parikh SA. "They arrested me for loving a schoolgirl": ethnography, $\mathrm{HIV}$, and a feminist assessment of the age of consent law as a gender-based structural intervention in Uganda. Soc Sci Med 2012;74:1774-82

136 Borrell LN. Editorial: critical race theory: why should we care about applying it in our research? Ethn Dis 2018;28:215-8.

137 Hardeman RR, Karbeah J'Mag, Kozhimannil KB. Applying a critical race lens to relationship-centered care in pregnancy and childbirth: an antidote to structural racism. Birth 2020;47:3-7.

138 Lee CJ. The necropolitics of COVID-19 in Africa is a country, 2020. Available: https://africasacountry.com/2020/04/the-necropoliticsof-covid-19

139 Spivak RGGC, Said E. Selected subaltern studies. Oxford University Press, 1988.

140 Guha R. A subaltern studies reader, 1986-1995. University of Minnesota Press, 1997.

141 Caxaj CS. Indigenous Storytelling and participatory action research: allies toward decolonization? reflections from the peoples' international health tribunal. Glob Qual Nurs Res 2015;2:2333393615580764.

142 Kingori P, Gerrets R. The masking and making of fieldworkers and data in postcolonial global health research contexts. Crit Public Health 2019;29:494-507.

143 McPhail-Bell K, Fredericks B, Brough M. Beyond the accolades: a postcolonial critique of the foundations of the Ottawa charter. Glob Health Promot 2013;20:22-9.

144 Mignolo WD, Walsh CE. Concepts On decoloniality:analytics, praxis. Durham, NC: Duke University Press, 2018.

145 Etzioni A. Mixed-scanning: a" third" approach to decision-making, 1967: 385-92

146 Buse K, Mays NB, Walt G. Making Health Policy. Open University Press, 2012.

147 Dalglish SL, Sriram V, Scott K, et al. A framework for medical power in two case studies of health policymaking in India and niger. Glob Public Health 2019;14:542-54.

148 Cairney P, Studlar D, Mamudu H. Global tobacco control: power, policy, governance and transfer. Springer, 2011.

149 Rushton S, Williams OD. Frames, paradigms and power: global health policy-making under neoliberalism. Global Society 2012;26:147-67.

150 Battams S, Townsend B. Power asymmetries, policy incoherence and noncommunicable disease control - a qualitative study of policy actor views. Crit Public Health 2019;29:596-609.

151 Kentikelenis A, Rochford C. Power asymmetries in global governance for health: a conceptual framework for analyzing the political-economic determinants of health inequities. Global Health 2019:15:70.

152 Bump JB, Reich MR. Political economy analysis for tobacco control in low- and middle-income countries. Health Policy Plan 2013:28:123-33.

153 Mann J. Health and human rights: broadening the agenda for health professionals. Health Hum Rights 1996;2:1-5.

154 Gruskin S. What are health and human rights? Lancet 2004;363:329.

155 Freedman LP. Health system strengthening: new potential for public health and human rights collaboration. Reprod Health Matters 2007;15:219-20.

156 Yamin AE, Norheim OF. Taking equality seriously: applying human rights frameworks to priority setting in health. Hum Rights $Q$ 2014:36:296-324.

157 Forman L. What future for the minimum core? Contextualizing the implications of SouthAfrican socioeconomic rights jurisprudence for the international human right to health. In: Global health and human rights: legal and philosophical perspectives. Routledge, 2009.

158 Erasmus E. The use of street-level bureaucracy theory in health policy analysis in low- and middle-income countries: a metaethnographic synthesis. Health Policy Plan 2014;29 Supp 3:iii70-8.

159 Walker L, Gilson L. 'We are bitter but we are satisfied': nurses as street-level bureaucrats in South Africa. Soc Sci Med 2004;59:1251-61. 